EPiC Series in Language and Linguistics
Volume 2, 2017, Pages 283-294
Professional and Academic Discourse:
an Interdisciplinary Perspective

\title{
A Semantics of the Financial Crisis in Spain
}

\author{
Keith Stuart ${ }^{1}$, Ana Botella ${ }^{1}$ and Lucia Gadea ${ }^{2}$ \\ ${ }^{1}$ Universidad Politécnica de Valencia, Valencia, Spain \\ ${ }^{2}$ Cadena Ser / El Pais, Spain \\ kstuart@idm.upv.es, apbotell@idm.upv.es, luciagadea@hotmail.com
}

\begin{abstract}
This article presents research carried out on a corpus of newspaper articles about the financial crisis in Spain (Corpus de la Crisis Financiera - CCF). The genesis and compilation of the CCF coincided with a growing body of publications about the financial situation in Spain, a severe economic downturn involving a banking crisis, a burst housing bubble, a dramatic increase in unemployment, and cuts in social services. In this paper, we are going to focus on the semantics and rhetorical functions in the different texts that make up the corpus. Our main objective is to explore the realizations of evaluative meaning in our corpus, either overtly expressed by the journalist or implicitly transmitted in texts by means of rhetorical devices such as metaphors.

We will provide examples from our corpus to show how the recurrence and coexistence of such linguistic features play a cohesive role providing texts consistency and texture. These linguistic resources persuade individual readers and even shape collective opinions and ideologies.
\end{abstract}

\section{Introduction: Analyzing Evaluation in a Spanish News Corpus}

This paper explores the linguistic resources of evaluative meanings in Spanish journalistic discourse. Three important aspects need to be considered with respect to the analysis of evaluative language in discourse. Firstly, we need to understand what we mean by evaluation; secondly, we have to decide how evaluation can be identified and, thirdly, how it can be analyzed at different levels of text.

The identification of evaluation can be complicated because it may be explicit or implicit. Even, apparently factual information may be value-laden. This may depend on the context of the information as well as the reader/writer interpretation of this information. In journalistic discourse, one has to be careful with who is the source of the evaluation. Evaluative meanings can originate in sources that are quoted by journalists. That is, the evaluations are found in speech that is directly marked in text as quoted using quotation marks or presented as indirect speech introduced by reporting verbs. It is therefore necessary to analyze the text closely to find out who is doing the evaluating. 
The CCF corpus contains the three main classes of genre in journalism: news, features, and editorials. In this study, we concentrate on editorials, as the defining characteristic of the editorial is the clear presence of the writer's opinion on a newsworthy topic of interest (in our particular case, the financial crisis in Spain and its socioeconomic impact). An editorial is persuasive and tries to convince the reader of the validity of the writer's position. The main purpose of an editorial as a genre is for the writer to evaluate and to be evaluated; the reader can be expected to choose to side with or against the writer based on the position the writer has presented. Like Ansary \& Babai (2005), we found that the basic generic prototypical pattern of text development for editorials is: Headline, Addressing an Issue, Argumentation, and Articulating a Position. More specifically, we found the headline to be evaluative, presenting a hypothesis and an implicit appeal to the reader. The main body of the text where the issue is addressed consisted of the statement of news and assessment of news. This is followed by argumentation and articulating a position. Finally, the ending of an editorial typically reformulates the headline and position presented in the text in the form of prediction of future events, call for action and an appeal to authority. As can be seen, this genre lends itself to evaluative meanings that are in abundance in this type of journalistic discourse.

In what follows, the paper is organized by introducing the linguistic notion of evaluation in text in section 2 (what is evaluation?). In sections 3 and 4, the methodological framework for identifying and analysing evaluation in our corpus is outlined (how can evaluation be identified?). In section 5 , we focus on the results of our analysis and concentrate on how evaluation acts at different levels to offer the reader a coherent persuasive argument. The paper concludes with some implications from the study.

\section{What is Evaluation?}

Evaluation is closely related to concepts such as affect (Batson, Shaw, \& Oleson, 1992), appraisal (Martin \& White, 2005), attitude (Halliday, 1994), point of view (Toolan, 2001), stance (Biber, 2006) and subjectivity (Traugott, 2010). More recently, linguistic studies of evaluation have been incorporated into the rapidly expanding field of Sentiment Analysis which is the use of natural language processing, text analysis and computational linguistics to identify and extract subjective information from diverse text sources (Taboada, 2016).

According to Thompson and Hunston (2003: 6), evaluation in discourse performs three functions: (1) it expresses the writer's opinion, and in doing so it reflects the value system of that person and their community; (2) it constructs and maintains relations between the writer and reader; and (3) it organizes the discourse.

Explaining the first ("expresses the writer's opinion”) of these three functions, they say, "every act of evaluation expresses a communal value-system, and every act of evaluation continues to build that value system. This value system in turn is a component of the ideology that lies behind every text". Therefore, for example, in the editorials we have analyzed there is very often a sentiment of being pro or against the Spanish President, Mariano Rajoy, depending on the ideology of the newspaper.

Explaining the second function of evaluation "maintaining relations", they discuss three main areas: manipulation, hedging, and politeness. Evaluation can be used to manipulate the reader, to persuade him or her to see things in a particular way. For example, the editorials often try to convince the reader that Rajoy is handling the financial crisis well (por lo menos, sabe el camino) or badly (la travesia por el desierto). When a writer is using manipulation or persuasion, Thompson and Hunston (2003: 8) claim that it takes a conscious effort of detachment on the part of the reader not to identify with the writer's point of view.

Evaluation also partakes in the organization of discourse. Thompson and Hunston (2003: 12) state that "evaluation which both organizes the discourse and indicates its significance might be said to tell the reader the 'point' of the discourse". Furthermore, "evaluation tends to be found throughout a text 
rather than being confined to one particular part of it” (Thompson and Hunston, 2003: 19). Evaluation is pervasive and acts as a thread, as part of the argument in editorials.

It is obvious that not all parts of a text contribute equally to the possible overall opinion expressed by the writer. Lexical items that are clearly evaluative are often adjectives (excellent-poor), but they can be nouns (problem-solution; triumph-tragedy), verbs (blame-credit), adverbs (fortunatelyunfortunately). There is a grammar of evaluation: comparisons, downtoners, emphatics/intensifiers, hedges, modality etc. Texts are organised around situation-evaluation or problem-response-evaluation. In the editorials from our corpus, the texts are organized around a typical structure of hypothesisargument-evaluation.

We can say that evaluation involves an event/institution/person/proposition/thing that is being evaluated. It involves the comparison of the object of evaluation against some standard (against readers' pre-conceived values of right and wrong). Evaluation is subjective; in text, markers of subjectivity are likely to be signalling that an expression of an attitude or an opinion is being voiced and that something is being classified as good-bad; positive-negative; expected-unexpected, important-unimportant etc. (Thompson and Hunston, 2003: 21-25). Finally, evaluation is value-laden; we are being asked to accept someone's opinions and, as readers, we can reject or make our own a writer's values.

\section{How Can Evaluation Be Identified in Text?}

Detecting patterns is a central part of corpus analysis. Words ending in -ed are often past tense verbs. More or an adjective ending in -er is indicative of a comparison being made and we know that evaluation involves comparisons. Observable patterns of word strings and word frequency tend to correlate with aspects of evaluative meanings. Drawing upon the concept of a local grammar of evaluation, Hunston \& Sinclair (2003: 84) examined two patterns: the $v$-link $+A D J+$ that pattern and the $v$-link $+A D J+$ to-inf pattern. These two patterns represent a viable and efficient diagnostic tool for retrieving instances of evaluative language. Adjectives indicate emotions, human qualities, qualities of things and attitudes.

As evaluation is ubiquitous in text (especially, in a genre such as the opinion article), there are many linguistic resources that may be correlated with aspects of evaluative meaning. In this paper, we focus mainly on rhetorical figures, for example, metaphor. In what follows, the methodological framework for identifying and analyzing evaluation in our corpus is outlined.

\section{Methodology: Analysis of Evaluation in the CCF Corpus}

The initial objective of our research was the collection of text and the design of a database of news publications related to the financial crisis in Spain for further analysis. The Financial Crisis Corpus (Corpus de la Crisis Financiera - CCF) consists of articles from the business and opinion sections of El País and El Mundo in 2012. These two newspapers are representatives in the press of Spanish bipartisan politics; as a result of the crisis, there are no longer two but four major political parties in Spain. The CCF was collected and analyzed quarterly, so that we could compare the results obtained in each period. The corpus was designed using a spreadsheet in a chronological manner. The spreadsheet included the following metadata: newspaper, date, author or editor of the article, journalistic genre, an identifier code (EP, OEM, OEP) with a hyperlink to each article, and the total number of words in the article (see Table 1 below). 


\begin{tabular}{cccccc}
\hline Newspaper & Date & Author / Editor & Article (genre) & Text id. & No. of words \\
\hline El País & $03 / 01 / 2012$ & $\begin{array}{c}\text { PAUL } \\
\text { KRUGMAN }\end{array}$ & Columna_opinión & OEP_03_01_12_[2] & 966 \\
El Mundo & $02 / 01 / 2012$ & $\begin{array}{c}\text { CARLOS } \\
\text { CUESTA }\end{array}$ & Columna_opinión & OEM 02_01_12 & 446 \\
\hline
\end{tabular}

Table 1: CCF_Metadata

The initial stages of the investigation involved the use of analytical methods that allowed us to discover what terms are the most frequent in the CCF and therefore to answer the question: what facts / what entities are noteworthy in the CCF corpus? This first analysis provided us with rather obvious evidence that the most common elements in the corpus refer to terms related to the economy, organizations, countries and characters involved in the financial crisis. Some examples of the most frequent words are: millions, governments, Spain, euro, debt, economy, bank, reform, crisis, deficit, entities, Greece, market, industry, labour, employment, businesses, measures, Europe, minister.

Similarly, through our list of frequencies, we saw who were the social actors or stakeholders in the crisis; this threw up personalities from Spanish political and economic life (Rajoy, Guindos, Montoro, Zapatero, Saenz de Santamaria, Báñez, Rato, Goigolzarri) and international economists and politicians (Merkel, Draghi, Monti, Cameron, Lagarde, Obama). Interestingly, these personalities vary in each quarter depending on events, whether the focus is on national news or takes on a European dimension. Having identified the social actors, entities and scenarios of the financial crisis, we set out to answer the following question: What opinions are expressed about these events and social actors? In order to carry this out, we analyzed the adjectives that collocated with these social actors. Appraisal Theory was used as a model for our analysis (Martin, 2000). The model has three main categories: Attitude, which refers to the different linguistic resources adopted to express positive or negative evaluation; Engagement, which comprises rhetorical resources concerned with those meanings which vary the terms of the speaker's engagement with the opinions presented; and Graduation, which explores the way the speakers assign grades or scales to the impact, force or volume of their propositions or to the focus of their semantic categorizations. Below are examples of adjectives detected in CCF for the category of Attitude and its subcategories. This has given us a framework with which it has been possible to contemplate the views, attitudes or emotions of journalists as categories or systems of meanings (Martin \& White, 2005: 42). 


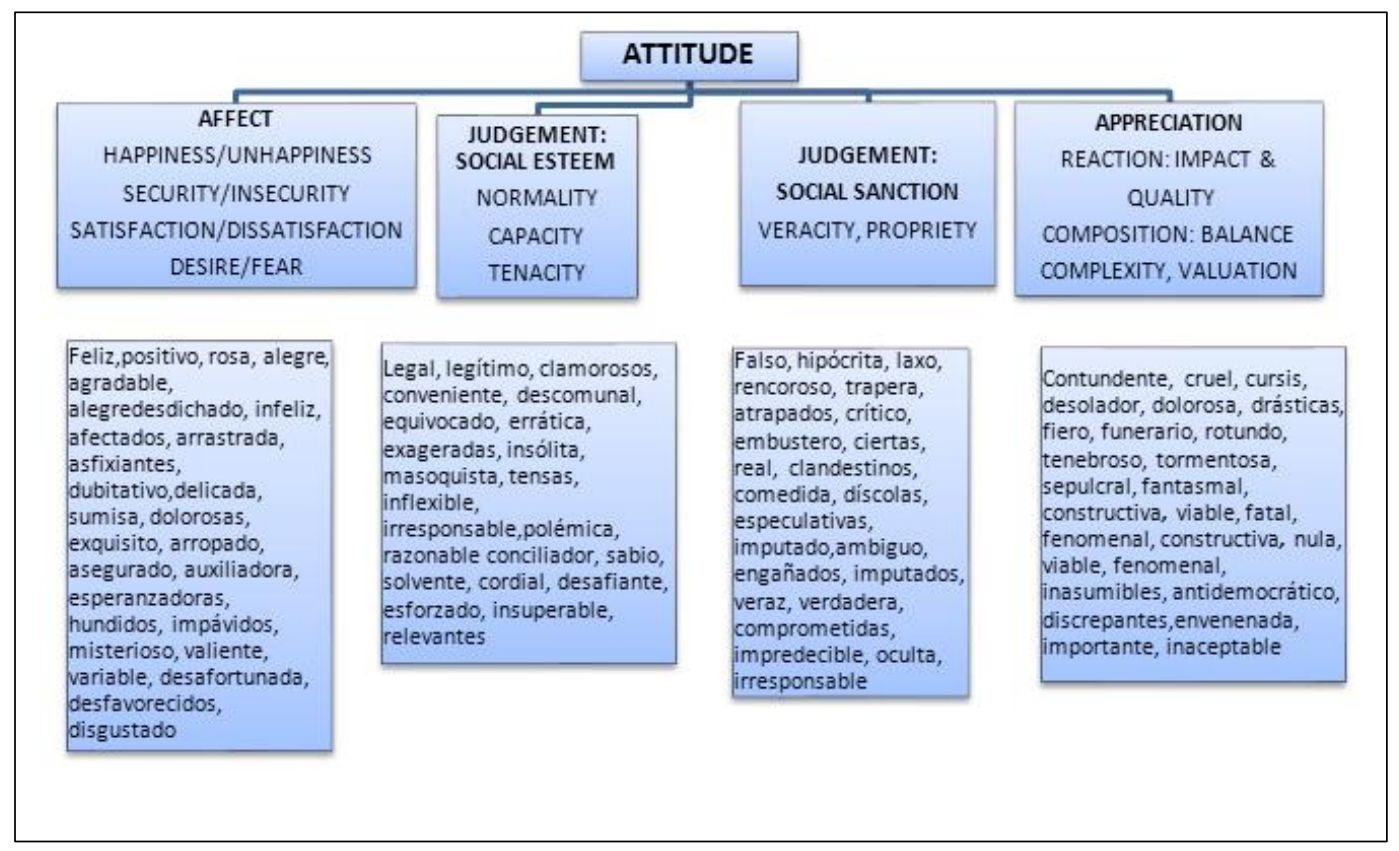

Figure 1: Attitude in the CCF corpus

Martin Herrero (2009) explains that, from the observation of concordance lines of linguistic matches, Corpus Linguistics offers a new vision of phraseology (of wordings): words alone are meaningless, unless we expand the horizons of these words. Hunston (2014: 12) states: 'collocation, concordance lines and wider context explicate the meaning, cultural or ideological significance, and function of the words and phrases so identified'.

Using this methodology, concordance lines matching our 12 social actors were analyzed quarterly for 2012. We focused on finding out who is doing the evaluation, what is the journalist really expressing in their message either with their own words, the words of the protagonists (political personalities) of the CCF or institutions involved in this process. That is, whose opinion is it? what do they think?, how does the article's author presents events or actions or words of the political personalities in the news story?

- Guindos avisa de que la recesión económica en España se agrava (What does Guindos say?)

- Alí Babá y los 659 evasores españoles puso la lista en manos de Cristóbal Montoro; si no trinca a los evasores es porque no le dejan (Who says this? How does Montoro behave?)

- Las altísimas expectativas que Mario Draghi había generado la semana pasada se han disuelto como un azucarillo (What does the writer think about Draghi?)

Focusing our analysis on phraseology and rhetorical devices, we added a comment manually for each concordance line, as can be seen below for Cristóbal Montoro, the Spanish Chancellor of the Exchequer:

- Montoro siembra dudas sobre la capacidad para cumplir el déficit (Metaphor "siembra dudas", Negative evaluation)

- El síndrome Merkel parece haber contagiado a Montoro (Metaphor for illness, Irony, Negative evaluation)

- Montoro tiene dentro un Stringer Bell aporreando calculadoras (Hyperbole, Negative evaluation) 
- Ahora Montoro anuncia poco menos que un revival de la Transición para cuadrar números (Irony, Negative evaluation)

- Montoro lo hará muy bien. De las Cortes de Cádiz viene ese galgo (Idiomatic use of language, Irony, Negative evaluation)

- Cristóbal Montoro y no es una servilleta arrugada donde alguien ha pintarrajeado un «8» (Metaphor, Negative evaluation)

- Para Cristóbal Montoro probablemente interpreten el Nessun dorma (nadie duerma) (Periphrasis, Intertextuality, Negative evaluation)

- Como ha expuesto el dibujante Montoro, en una viñeta digna de Mingote (Irony, Intertextuality, Negative evaluation)

- $\mathrm{Al}$ acabar el telediario debería salir Montoro con un palo frente a un mapa señalando los déficits (Irony, Negative evaluation)

As mentioned previously, the analysis of the different social actors and their context revealed various nuances in the form of multifarious linguistic realizations, which we classified with a series of labels, presented below with examples.

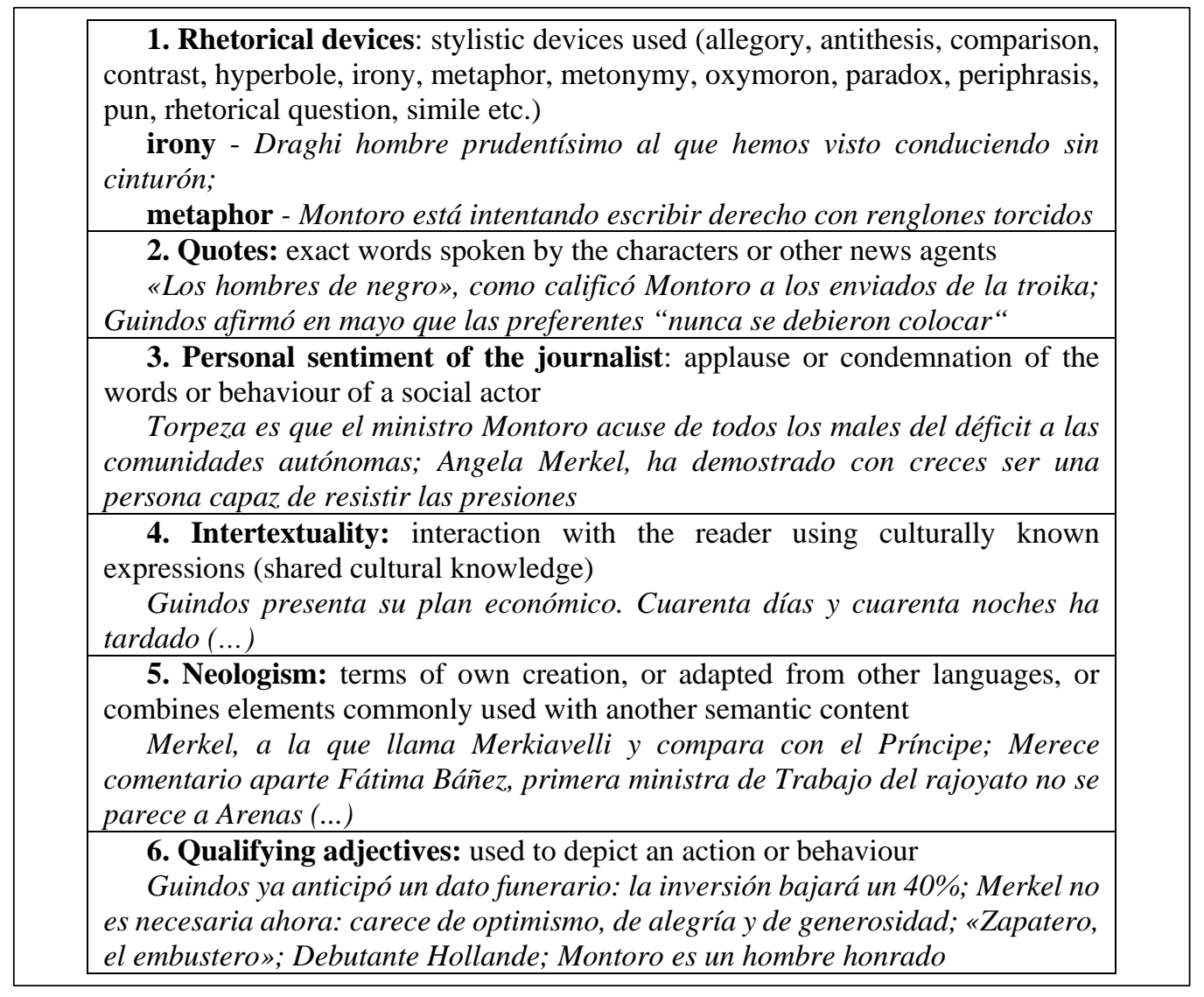

Table 2: Linguistic realizations of evaluation of social actors in the CCF corpus

In the next phase of the research, we analyzed the concept of evaluation taking into account units of varying complexity and different levels of text. 


\section{Results: Analysis of Evaluation at Different Text Levels}

The observation of text samples obtained by the method described above has led us to reflect and draw conclusions about the nature of evaluative expressions: evaluation can be manifested explicitly, by selecting terms and expressions that are overtly evaluative; but can also be realized in text implicitly, hidden behind rhetorical figures. In turn, evaluation can be seen locally (in words, phrases, sentences) or be present globally, a continuous thread throughout a text (in our case, in a newspaper article) by using different strategies which we describe and exemplify below.

\subsection{Explicit Evaluation}

Certain grammatical structures constitute an overt form of realization of attitudinal markers on the part of the journalist, such as deontic modals, attitudinal adverbs and the structure 'to be' + evaluative adjective or a comparative adjective.

- $\quad$ debe acometer sin demora los deberes que ya tenía impuestos; una incógnita que debe despejarse; tendríamos que volver a la sencillez aforística

- $\quad$ han aprovechado de nuestro dinero impunemente; el sistema está perversamente diseñado

- La responsabilidad de las autonomías en el desvío del déficit es dramática e incontestable

- $\quad$ Pero el problema es mucho más profundo que el incumplimiento de 2011

Adjectives convey much of the subjective content in a text. A great deal of effort has therefore been devoted to extracting semantic orientation for adjectives whether they be positive or negative. These, along with modals, comparatives, conditionals, intensifiers, downtoners, are all explicit forms of evaluation and have been covered in the literature (see Dafouz, 2006, 2008).

\subsection{Implicit Evaluation in the CCF}

More interestingly and less covered in the literature are the examples below. The terms and expressions (adjectives, nouns, verbs) that have been underlined such as: respaldado, sabio, buena, consigue, le dio una lección, gentileza, aderezar may all be considered positive, if it were not for the context. As can be observed from the context, the message in all these examples is negative, masked behind a layer of irony.

- $\quad$ Negative: los mercados han respaldado la gestión de Monti mucho más que la de Rajoy

- $\quad$ Negative: El sabio Cristóbal Montoro no ha meditado sobre el punto más vidrioso de su propuesta

- $\quad$ Negative: Buena jugadora, Angela Merkel consigue vendernos las migajas

- Condemnation: Cristóbal Montoro le dio una lección acerca de cómo se miente en público

- $\quad$ Applause: Merkel ha tenido la gentileza de aderezar un pastel

Likewise, what may appear to be in principle a fairly neutral statement given that none of the words have a negative or positive connotation is in fact through the rhetorical use of a simile a negative statement. Manual interpretation reveals that the statement has negative overtones by making reference to a meeting that both political leaders will attend, to deal with the serious financial problems of Spain (Draghi is metaphorically compared to a doctor and Guindos is the sick patient representing the whole of Spain).

- $\quad$ Negative: Guindos tiene hora con Mario Draghi como quien la tiene con un médico

There are other similar examples where the doctor-patient metaphor is extended (dottore, píldora, operación de drenaje de liquidez)

- $\quad$ el dottore Draghi, actuando de la peor manera posible

- $\quad$ una píldora que Draghi ve absolutamente necesaria 
- La institución presidida por Mario Draghi realizará mañana una operación de drenaje de liquidez

On occasions, journalists recur to colloquialisms and neologisms, because they want to capture the attention of the reader and use expressions that are understandable to the average person. Through these linguistic resources, the reader is entertained by the writer's use of the language of daily conversations, situating the reader and writer at the same level (dicho en más suave, rojerío, racaneo, cabezas de chorlito, puñalada trapera, adefesio garlero, requetehistórica cumbre). This same effect can be achieved with expressions coined by the journalists themselves where they normally take as the base form names and nouns related to politicians to which they add prefixes and/or suffixes (zapatético, zapateresco, pepero, rajoyato, Merkiavelli). The text takes on a light-hearted and dynamic pace, full of great expressiveness. The sting and venom of negative irony is replaced by humour.

The persuasive character of journalistic discourse means the writer will hide behind the text their real message. In this way, resorting to varying stylistic resources, their language is embellished and the reader is forced to decode and interpret the contents of the article (to evaluate an event or institution or the words pronounced by a famous personality) and arrive at their own conclusions. The primary objective will be to convince the interlocutor that the author is right and "telling the truth".

A frequent linguistic resource used in our corpus is irony (as we have already seen). It is often used to ridicule a personality or a situation, or contradict what we really mean to say.

- Draghi hombre prudentísimo al que hemos visto conduciendo sin cinturón

- Para Cristobal Montoro probablemente interpreten el Nessun dorma

- se escandalizaba porque Zapatero se atrevió a subir el IVA de «los chuches»

- Hollande, que tiene pinta de profesor de guardería venido a menos

- Buena jugadora, Angela Merkel consigue vendernos las migajas

Metaphor is another recurrent rhetorical figure in the corpus. Irony is often combined with metaphor in text (diabólico tripartito, el clan de "los mejores", el síndrome Merkel parece haber contagiado a Montoro). Analysis of our corpus has shown that journalists frequently use metaphor to create images of reality with which they express a greater number of meanings with fewer words. Figurative language helps the reader to interpret the text and accept or question the values being implicitly espoused. In this sense, they are a powerful tool for the creation and spread of ideologies.

The metaphors in the corpus refer to sports, advertisements, religion, cinema, historical facts (wars), science or literature. They often refer to things, which are familiar to the reader, expressions from a common lexicon.

- Guindos echó balones fuera: "Tenemos que ver cuál es la inflación de noviembre"

- Guindos asegura que "las reformas empiezan a dar sus frutos"

- Zapatero esparció las siembras de Caín sobre los surcos de Cataluña

- Esto sí que era un algoritmo de altos vuelos. Guindos se ha convertido así en alguien como el doctor Hoffmann

\subsection{Interaction with the Reader and Evaluation}

Logical reasoning in text can be seen as a dialectic game, where the writer attempts to convince a reader of the truth of a proposition. This dialectic game, in the words of Thompson and Thetela (1995) 'the reader-in-the-text', by which the reader and writer exchange opinions, is achieved through the inclusion of the audience in the text itself by the writer directing their discourse at the reader with imperatives or vocatives (miren, imaginen, ya ven, comparen, cabe preguntarse, no debe olvidarse que), inclusive expressions such as $1^{\text {st }}$ person plural pronouns, which situate the writer closer to the reader (nos ha hecho esclavos, nos causan, que le hemos dado, nos lleva, nos ha conducido) and through the use of rhetorical questions. Rhetorical questions ask the reader to reflect on an issue and, 
later in the text, the reader often finds the answer to the question or has to answer the question themself.

- ¿ ¿Logrará Merkel domesticar la animalidad de los mercados?

- ¿Cómo va a recuperar lo que no ha perdido? O mentía en la primera parte de la proposición o mentía en la segunda, aunque, conociéndole, quizá mintiera en las dos.

- $\quad$ - ¿Ha habido despilfarro? Por supuesto.

Using quotes is a mechanism with which the writer keeps a distance from the words others have spoken. In the CCF corpus, the author of an article often reproduces the exact words of the social actors. We can interpret this as a way of emphasizing the content within quotes, which is simultaneously being implicitly evaluated.

- $\quad$ "Las dificultades de liquidez son una auténtica oportunidad para imponer duras condiciones" (...) como se sinceró Luis de Guindos

- "le hace un flaco favor al Estado de bienestar", comenta Vilalta

- "ninguna prestación sin contrapartidas" dice Merkel

- Rajoy prepara "medidas contundentes"

In the following section, we will see how evaluation is distributed and dispersed throughout a text (an editorial), acting as a tool that contributes to cohesion and textual organization.

\subsection{Evaluation throughout the Text}

People who want to know the state of public opinion in a country read editorials with interest. Governments consider this genre a very important source of information as an interpretation of the media on their decisions. In the text below, we analyze an editorial and observe how the journalist compresses into the first paragraph a series of lexical items with negative connotations (despilfarro, megalomanía, excesos, disparates, descaro, causas más peregrinas, pufos y mentira del déficit).

La crisis tiene su parte positiva

Gracias a la crisis están saliendo a relucir el despilfarro, la megalomanía y los excesos de nuestros gobernantes. A nivel nacional conocimos los disparates del Plan E, los 400 euros de ZP para comprar el voto de 2008 con el mayor descaro, y las donaciones y subvenciones a las causas más peregrinas del mundo a cargo de las ministras de cuota. Luego han salido más pufos y la mentira del déficit.

Pero con el anuncio de la aportación del Estado para pago a los proveedores de ayuntamientos se ha destapado la caja de pandora: las facturas de hace décadas y los cientos de miles de deuda en poblaciones de 200 habitantes. Bienvenida sea la ruina si sirve para que se sonroje la caterva de políticos ineptos, pésimos administradores, presumidos electoralistas, que nos han llenado el país y la vida de rotondas, polideportivos vacíos, farolas y setos al más puro estilo hortera y nuevo rico. Los ciudadanos con algo de sentido común hace tiempo que temíamos que esto iba a explotar, que España tuviera más aeropuertos por kilómetro cuadrado que el resto de Europa y las fachadas más rimbombantes y subvencionadas. ¿En manos de quién estamos? ¿Qué cabezas de chorlito se han aprovechado de nuestro dinero impunemente para satisfacer su ego y comprar votos (esto sin hablar de la corrupción)? Hay que desmantelar este régimen de desaprensivos, levantar las alfombras y sanear la casa de una vez. Ahora o nunca.

The expressions in the text are grouped under evaluative labels that meet the communicative functions previously described in this article and that often co-occur in the same sentence or paragraph (extended metaphors, the language of contradiction that leads to antithesis and oxymoron with an ironic tone or euphemisms). All these rhetorical effects are less direct and soften ideas that might come across as being a bit hard. This repetition or reformulation of ideas produces a semantic prosody, which can also be appreciated in those calls to the reader through inclusive expressions or the recurrent use of rhetorical questions. 
a) Oximoron + Repetition:

- La crisis tiene su parte positiva; Gracias a la crisis; Bienvenida sea la ruina (irony)

b) Metaphor:

- $\quad$ se ha destapado la caja de pandora; nos han llenado el país y la vida de rotondas

c) Plural expressions (inclusive expressions):

- $\quad$ conocimos los disparates; nuestros gobernantes

- Los ciudadanos con algo de sentido común hace tiempo que temíamos que esto iba a explotar

d) Deontic modality:

- Hay que desmantelar este régimen de desaprensivos; podía ser que

e) Rhetorical questions (direct) + reply:

- ¿ ¿En manos de quién estamos? ¿Qué cabezas de chorlito se han aprovechado de nuestro dinero impunemente para satisfacer su ego y comprar votos (esto sin hablar de la corrupción)? Reply (by means of a question) to previous question

f) The 'Rule of Three' to create engaging content (a way to structure ideas):

- $\quad$ el despilfarro, la megalomanía y los excesos

- $\quad$ políticos ineptos, pésimos administradores, presumidos electoralistas

g) Coloquialisms:

- $\quad$ nos han llenado el país y la vida de rotondas, polideportivos vacíos, farolas y setos al más puro estilo hortera y nuevo rico; fachadas más rimbombantes y subvencionadas

The macrostructure of the text is the following:

\begin{tabular}{|l|}
\hline Macro-structure of text (OEM_19_03_12_[2]) \\
\hline Headline: evaluative (irony + antithesis) /appeal to reader (implicit) \\
Body: Journalist presenting the news / Journalist expressing his opinion about the \\
government performance/ \\
Body: Journalist assessing government performance (Zapatero's government): \\
assessing his lack of credibility \\
Ending: Call for action / appeal to authority
\end{tabular}

Table 3: Sample Text: Macrostructure

Finally, we would like to highlight the continued use of stylistic devices, which often involves reformulating the same linguistic resource, providing the text with texture and consistency. Take, for example, the repetition of the Latin oratorical phrase "Delenda est Carthago" in the text below (Table 4). The journalist is using this recurrent rhetorical figure in order to emphasize to the reader the strength of a third party's opinion about a perceived necessary course of action but undermining it with irony and negative connotations. 
(OEP_01_03_12_[2]) Delenda est autonomia

Lead: Las comunidades son las responsables del mayor desvío en el déficit, pero el grueso es del Estado

Body: Delenda est Carthago -Cartago debe ser destruida-, proclamaba el senador romano Catón, con ocasión y sin ella, un siglo y medio antes de Cristo.

Delenda est Monarchia, escribió José Ortega el 15 de noviembre de 1930 en El Sol, sembrando el camino a la República.

Delenda est autonomia, sugieren algunos desde que la FAES publicó en 2010 su pionero estudio Por un Estado autonómico racional y viable, que abrió paso a la gran campaña contra el "despilfarro" regional.

Table 4: Repetition of rhetorical devices

\section{Conclusion}

The analysis of evaluation in text poses significant methodological challenges, which mainly arise from the fact that: a) evaluative meanings can be expressed through an open-ended range of lexicogrammatical resources; b) they can span multiple words and whole texts; c) context and co-text play a key role in determining the evaluative meaning of words or phrases; d) the interpretation of evaluation in text depends on the reader's/analyst's point of view.

Despite these complexities, the development of a corpus-driven description of this phenomenon in our corpus has provided relevant findings about the semantic choices made about the financial crisis in Spain, especially concerning rhetorical devices (repetition, metaphor, irony, intertextuality etc.) and interpersonal metadiscourse as key linguistic resources to persuade individual readers and even shape collective opinions and ideologies.

\section{References}

Ansary, H., \& Babai, E. (2005). The Generic Integrity of Newspaper Editorials: A Systemic Functional Perspective. RELC Journal, Vol 36, No 3, 271-295.

Batson, C., Shaw, L., \& Oleson, K. (1992). Differentiating affect, mood, and emotion: Toward functionally based conceptual distinctions. In M. Clark, Review of personality and social psychology (pp. 95-113). Newbury Park, Ca: Sage.

Biber, D. (2006). Stance in spoken and written university registers. Journal of English for Academic Purposes, 5-2, 97-116.

Dafouz, E. (2006). Estudio de los marcadores interpersonales en el comentario periodístico: estrategias para la identificación autor-lector en el texto. RESLA: Revista española de lingüística aplicada, (19), 67-82.

Dafouz-Milne, E. (2008). The pragmatic role of textual and interpersonal metadiscourse markers in the construction and attainment of persuasion: A cross-linguistic study of newspaper discourse. Journal of Pragmatics, 40(1), 95-113.

Halliday, M. A. (1994). Introduction to Functional Grammar. London: Edward Arnold.

Herrero, C. (2009). Aproximación a ciertas perspectivas en Lingüística de Corpus. In P. Cantos, \& A. Sánchez, A Survey on Corpus-based Research/Panorama de investigaciones basadas en corpus [Recurso electrónico] (pp. 1020-1032). Asociación Española de Lingüística del Corpus.

Hunston, S. (2014). Flavours of Corpus Linguistics. Paper given at Charles University, Prague 2012 and at Corpus Linguistics 2011, Birmingham. 
Hunston, S., \& Sinclair, J. (2003). A local grammar of evaluation. In S. Hunston, \& G. Thompson, Evaluation in text: Authorial stance and the construction of discourse (pp. 74-101). Oxford: Oxford University Press.

Martin, J. (2000). Beyond Exchange: Appraisal systems in English. In Hunston, S. and Thompson, G., Evaluation in text (pp. 142-175). Oxford: Oxford University Press.

Martin, J., \& White, P. R. (2005). The Language of Evaluation, Appraisal in English. London: Palgrave Macmillan.

Taboada, M. (2016). Sentiment Analysis: An Overview from Linguistics. Annual Review of Linguistics, Vol.2, 325-347.

Thompson, G., \& Hunston, S. (2003). Evaluation: An introduction. In S. Hunston, \& G. Thompson, Evaluation in text: Authorial stance and the construction of discourse (pp. 1-27). Oxford: Oxford University Press.

Thompson, G., \& Thetela, P. (1995). The Sound of one hand clapping: The management of interaction in written discourse. Text-Interdisciplinary Journal for the Study of Discourse, 15(1), 103128.

Toolan, M. (2001). Narrative: A critical linguistic introduction. Routledge.

Traugott, E. (2010). (Inter) subjectivity and (inter) subjectification: a reassessment. In K. Davidse, L. Vandelanotte, \& H. Cuyckens, Subjectification, Intersubjectification and Grammaticalization (pp. 29-71). De Gruyter Mouton. 